Stephen D Herald ${ }^{1}$, Paul M Frisby ${ }^{2}$, and Samuel Eddie Davis ${ }^{3}$

\title{
Oxygen Compatibility of Brass-Filled PTFE Compared to Commonly Used Fluorinated Polymers for Oxygen Systems
}

\begin{abstract}
Safe and reliable seal materials for high-pressure oxygen systems sometimes appear to be extinct species when sought out by oxygen systems designers. Materials that seal well are easy to find, but these materials are typically incompatible with oxygen, especially in cryogenic liquid form. This incompatibility can result in seals that leak, or much worse, seals that easily ignite and burn during use. Materials that are compatible with oxygen are easy to find, such as the long list of compatible metals, but these metallic materials are limiting as seal materials. A material that seals well and is oxygen compatible has been the big game in the designer's safari.
\end{abstract}

Scientists at the Materials Combustion Research Facility (MCRF), part of NASA/Marshall Space Flight Center (MSFC), are constantly searching for better materials and processes to improve the safety of oxygen systems. One focus of this effort is improving the characteristics of polymers used in the presence of an oxygen enriched environment.

\footnotetext{
${ }^{1}$ Test Group Lead Engineer, INFOPRO CORP., Materials Test Branch, Materials Combustion Research Facility NASA George C. Marshall Space Flight Center, Huntsville, AL 35812 USA.

${ }^{2}$ Materials Engineer, INFOPRO CORP., Materials Test Branch, Materials Combustion Research Facility NASA George C. Marshall Space Flight Center, Huntsville, AL 35812 USA.

${ }^{3}$ Materials Engineer, NASA, Materials Test Branch, Materials Combustion Research Facility NASA George C. Marshall Space Flight Center, Huntsville, AL 35812 USA.
} 
Very few systems can be built which contain no polymeric materials; therefore, materials which have good impact resistance, low heat of combustion, high auto-ignition temperature and that maintain good mechanical properties are essential. The scientists and engineers at the Materials Combustion Research Facility, in cooperation with seal suppliers, are currently testing a new formulation of polytetrafluoroethylene (PTFE) with Brass filler. This Brass-filled PTFE is showing great promise as a seal and seat material for highpressure oxygen systems. Early research has demonstrated very encouraging results, which could rank this material as one of the best fluorinated polymers ever tested.

This paper will compare the data obtained for Brass-filled PTFE with other fluorinated polymers, such as TFE-Teflon ${ }^{\circledR}\left(\right.$ PTFE) , Kel-F® 81 , Viton ${ }^{\circledR}$ A, Viton ${ }^{\circledR}$ A-500, Fluorel ${ }^{\circledR}$, and Algoflon®. A similar metal filled fluorinated polymer, Salox-M ${ }^{\circledR}$, was tested in comparison to Brass-filled PTFE to demonstrate the importance of the metal chosen and relative percentage of filler. General conclusions on the oxygen compatibility of this formulation are drawn, with an emphasis on comparing and contrasting the materials performance to the performance of the current state-of-the-art oxygen compatible polymers.

KEYWORDS: Oxygen Systems, Polytetrafluoroethylene, Fluorinated Polymers, MAPTIS 


\section{Introduction}

Safe and reliable seal materials for high-pressure oxygen systems sometimes appear to be extinct species when sought out by oxygen systems designers. Materials that seal well are easy to find, but these materials are typically incompatible with oxygen, especially in cryogenic liquid form. This incompatibility can result in seals that leak, or much worse, seals that easily ignite and burn during use. Materials that are compatible with oxygen are easy to find, such as the long list of compatible metals, but these metallic materials are limiting as seal materials. A material that seals well and is oxygen compatible has been the big game in the oxygen system designer's safari.

Scientists at the Materials Combustion Research Facility (MCRF), part of NASA/Marshall Space Flight Center (MSFC), are constantly searching for better materials

and processes to improve the safety of oxygen systems. One focus of this effort is improving the characteristics of polymers used in the presence of oxygen. Very few systems can be built which contain no polymeric materials; therefore, materials which have good impact resistance, low heat of combustion, high auto-ignition temperature and that maintain good mechanical properties are essential.

\section{The Search for a Better Polymer}

Polymeric materials are widely used as seals and seat materials in oxygen systems. One of the most frequent causes of fires in oxygen systems using polymeric materials is ignition of the polymer which promotes to surrounding materials and results in a catastrophic failure. According to previous studies [1] the most compatible materials in oxygen systems are fluorinated polymeric materials such as PTFE and PCTFE. This 
measure of compatibility is determined by favorable characteristics for oxygen use such as high oxygen index (ignition resistance), low heat of combustion, and high auto-ignition temperature. This knowledge has allowed the MCRF, in conjunction with other groups within MSFC, to begin to experiment with different PTFE and PCTFE based polymers. From both internal experience and previous studies, metal filled polymers seem to be the key to improved properties among oxygen compatible materials.

\section{Existing Data Library}

The data used to compare Brass-filled PTFE to other polymers was obtained from other ASTM papers as well as NASA's Materials and Processes Technical Information System (MAPTIS). The MAPTIS database is housed at the NASA George C. Marshall Space Flight Center and is available to the public, with minimal limitations, at the web site http://maptis.nasa.gov.

\section{Experimental}

\section{Test Apparatus}

The data discussed in this paper were obtained by the use of both in-house equipment and the use of preexisting documented results. The Brass-filled PTFE samples discussed in this paper were evaluated using a Parr 6200 oxygen bomb calorimeter to determine the heat of combustion. Three other testers were also required in order to provide necessary data. These were the inhouse ambient-pressure mechanical impact, high-pressure mechanical impact, and autogenous ignition temperature (AIT) testers. Heat of combustion, AIT, ambient and high-pressure mechanical impact experiments were conducted in accordance with ASTM G-72, ASTM G-86, ASTM D-4809 and NASA-STD-6001, respectively. 


\section{Procedure}

Heat of combustion - The measurement of the heat of combustion was calculated internally by the software programmed on the Parr 6200 , which was verified by comparison to a benzoic acid standard supplied by Sigma Aldrich. The heat of combustion sample was placed inside a metallic combustion cup, and an ignition wire was positioned above the sample as to touch the top of the sample but not come in contact with any metal other than the terminal leads. In order to assure that combustion will occur, a mineral oil spike was used, and for which the calculations corrected. The combustion chamber was sealed and pressurized with GOX, lowered into the water bath, and the ignition wire leads were attached to the top of the combustion chamber. After the test was over, the calorimeter displayed the gross heat content of the sample in calories per gram weight of sample.

Autogeneous Ignition Test-The samples for AIT were prepared per the standard and placed into a small glass test tube. The test tube was placed into the sample holder and a thermocouple was positioned inside the test tube near the sample. The chamber was purged several times with GOX to insure a $100 \%$ oxygen environment prior to pressurizing the chamber to the test pressure. Once the test pressure was reached, the system was monitored in order to assure that the chamber was properly sealed. The external heater was started and allowed to increase the temperature of the sample at a rate of 9 degrees $\mathrm{F} / \mathrm{min}$. The indication of autogenous ignition was the rapid increase of temperature and pressure. If the system temperature rises above $425^{\circ} \mathrm{C}$ prior to ignition of the sample, then the AIT is recorded as $>425^{\circ} \mathrm{C}$.

Mechanical Impact Test-For ambient-pressure mechanical impact testing, samples were positioned in the test chamber, which was cryogenically cooled with Nitrogen, and submerged in LOX. The samples were impacted with 98 Joules of energy (72 ft-lbs) while reactions were 
detected by the operator in terms of a visual flash or audible noise. The high-pressure mechanical impact test can be operated in a LOX or GOX mode, depending on the parameters of the test. In order to achieve $100 \%$ oxygen inside the test chamber, several lower pressure oxygen purges were required prior to the chamber being pressurized to the full test pressure. Once the chamber was brought up to the required test pressure, the plummet was allowed to impact the sample at 98 Joules of energy ( $72 \mathrm{ft}-\mathrm{lbs})$. The detection of a reaction was indicated by the illumination of a photodiode, which was positioned outside of the chamber with an optical viewing port. After several series of tests were conducted for both ambient and high-pressure mechanical impact, the samples were analyzed for signs of combustion that may not have been detected by the operator or equipment. The pass/fail criterion for a material, in both ambient and high-pressure mechanical impact, is determined by the number of reactions recorded in a series of tests. A sample is said to have passed the mechanical impact test at the given pressure and temperature if no reactions are recorded out of 20 samples. If one sample out of 20 reacts, then 40 additional samples must be tested without any reactions in order for the material to pass the test.

\section{Results and Discussion}

Previous research conducted by Chou and Giedorowicz examined several fluorinated polymeric materials that are of interest in the further characterization of Brass-filled PTFE including: TFE-Teflon ${ }^{\circledR}\left(\right.$ PTFE), Kel-F® 81 (PCTFE), Viton ${ }^{\circledR}$ A, Viton ${ }^{\circledR}$ A-500, and Fluorel®. In Table 1, heat of combustion data for the Fluorinated compounds are presented as an average of three tests according the ASTM Standard D-3286 along with a standard deviation calculated from the presented data. The heat of combustion data for Brass-filled PTFE presented in Table 2 was determined by the MCRF at MSFC. The caloric content per gram of material for Brass- 
filled PTFE was $12 \%$ lower than the caloric content of the non-Brass-filled PTFE determined by Chou and Giedorowicz. The reported values for the heat of combustion of TFE-Teflon ${ }^{\circledR}(\mathrm{PTFE})$ in the Safe Use of Oxygen and Oxygen Systems vary substantially between the different test facilities with an average of 1483 (cal/gram) and standard deviation of 208 (cal/gram) [2]. Although this value is lower than that reported by Chou and Giedorowicz, their value still falls within the acceptable range of error.

The lower heat of combustion of the Brass-filled PTFE further exemplifies the material's compatibility in oxygen systems. The comparison of Brass-filled PTFE to the other Fluorinated polymers studied by Chou and Giedorowicz in terms of heat of combustion, shows that Brassfilled PTFE has a 48\% lower caloric content than Kel-F® 81 (PCTFE) and a 66\% lower caloric content per gram than Viton ${ }^{\circledR}$ A, Viton ${ }^{\circledR}$ A-500, and Fluorel ${ }^{\circledR}$. As defined in the ASTM and NASA-STD-6001A standards for AIT testing, a sample that ignites above a temperature of 425 ${ }^{\circ} \mathrm{C}$ is recorded as having an AIT temperature $>425{ }^{\circ} \mathrm{C}$ and the actual value is not specified. Due to this limitation, the only comparison that can be made between the Brass-filled PTFE and Teflon $\AA$ is that they both auto ignite above $425^{\circ} \mathrm{C}$ and both materials experience a pressure rise of roughly 700 psi, which can be seen in Tables 3 and 4 . When compared to the other materials, Brass-filled PTFE has an AIT value 44\% greater than both Viton ${ }^{\circledR}$ A and Viton ${ }^{\circledR}$ A-500 and 30\% greater than Fluorel $\AA$. These percentages are only valid for the comparison of an AIT value that is below the maximum test temperature of $425^{\circ} \mathrm{C}$.

The determination that a material is oxygen compatible cannot be made exclusively by AIT and heat of combustion data. A good example of the need for several different parameters to be considered in the criteria for an oxygen compatible material is evident upon the comparison of the AIT data of Brass-filled PTFE and Kel-F® 81 (PCTFE). The AIT for Brass-filled PTFE is 
only 5\% higher than for Kel-F® 81 (PCTFE) based on the maximum temperature threshold in the standard. As mentioned previously, the heat of combustion for Kel-F® 81 (PCTFE) is 48\% higher than that of the Brass-filled PTFE, which indicates that, upon ignition, the material can supply $48 \%$ more energy into the burning system.

TABLE $1-$ Heat of combustion results for Fluorinated compounds

\begin{tabular}{ccc}
\hline Material & heat of combustion (cal/gram) & Standard Deviation (cal/gram) \\
\hline${ }^{\mathrm{a}}$ TFE-Teflon ${ }^{\circledR}$ (PTFE) & 1517 & 24.33 \\
${ }^{\mathrm{a}}$ Kel-F® 81 (PCTFE) & 2556 & 17.09 \\
${ }^{\mathrm{a}}$ Viton ${ }^{\circledR ~ A ~}$ & 3992 & 18.01 \\
${ }^{\mathrm{a}}$ Viton ${ }^{\circledR}$ A-500 & 3934 & 11.06 \\
${ }^{\mathrm{a}}$ Fluorel ${ }^{\circledR}$ & 3992 & 16.74 \\
${ }^{\mathrm{b}}$ Brass-filled PTFE & 1332 & 13.81 \\
\hline
\end{tabular}

a- $\quad$ ASTM D328 Chou and Giedorowicz

b- NASA-STD-6001

TABLE 2-AIT Data of Fluorinated Compounds

\begin{tabular}{|c|c|c|c|}
\hline Material & AIT $\left({ }^{\circ} \mathrm{C}\right)$ & $\begin{array}{l}\text { Initial Test Pressure } \\
\text { (psia) }\end{array}$ & $\begin{array}{c}\text { Final Test Pressure } \\
\text { (psia) }\end{array}$ \\
\hline${ }^{\mathrm{a} T F E-T e f l o n}{ }^{\circledR}$ (PTFE) & $>425$ & 1500 & 2200 \\
\hline${ }^{\mathrm{a}} \mathrm{Kel}-\mathrm{F} 囚 81$ (PCTFE) & 404.3 & 1500 & 2200 \\
\hline${ }^{\mathrm{a}}$ Viton ${ }^{\circledR} \mathrm{A}$ & 239 & 1500 & 2000 \\
\hline${ }^{\mathrm{a}}$ Viton ${ }^{\circledR}$ A-500 & 239 & 1500 & 2000 \\
\hline${ }^{\mathrm{a}}$ Fluorel ${ }^{\circledR}$ & 296 & 1500 & 2100 \\
\hline${ }^{\mathrm{b}}$ Brass-filled PTFE & $>425$ & 1500 & 2268 \\
\hline${ }^{\mathrm{b}}$ TFE-Teflon ${ }^{\circledR}$ (PTFE) & $>425$ & 1500 & 2396 \\
\hline
\end{tabular}


Another test used to assess the viability of a material in a liquid or gaseous oxygen environment is the Mechanical Impact Test. The data presented by Chou and Giedorowicz is only an indication of whether or not the material passed the test according to the ASTM standard. Their data indicates that only TFE-Teflon ${ }^{\circledR}$ (PTFE) passed the mechanical impact test in a LOX environment at ambient pressure. Figure 1, below, is a pretest picture of the Brassfilled PTFE, which is blue in color and came pre-cut into a circular sample from the distributor. Although the name indicates that the material is Brass-filled, the small slivers cannot be seen on the surface in the picture. A post-test picture of a Brass-filled PTFE sample was taken in order to show how the material behaves upon a non-reacting, high energy contact, which can be seen in Figure 2. A post-test picture of a reacting sample was not taken due to complete combustion of the sample in a LOX environment. The post-test picture of a non-reactive sample shows that the material is extruded in an outward radial direction when it is struck by the pin. Part of the sample was trapped under the pin, generating a thin compressed layer. A small sliver of the Brass filling can be seen in the center of the compressed layer.

The mechanical impact data for the Brass-filled PTFE, and several other PTFE materials tested at MSFC, in both LOX and GOX environments, can be seen in Table 3. The data shows that Brass-filled PTFE is highly compatible with both LOX and GOX systems. It was impacted with 98 Joules at 10,000 psia in both LOX and GOX according the NASA-STD-6001 and passed in both environments with no reactions out of 20 samples. In order to assure the accuracy of the data, an additional 80 samples of the same batch of Brass-filled PTFE were tested in LOX and GOX. Each was impacted with 98 Joules at 10,000 psia in LOX and in GOX. Neither the LOX nor GOX tests showed any reactions out of the 80 impacts. Four of the additional 80 LOX samples reacted with no remaining sample in the cup. A second batch of the Brass-filled PTFE 
was tested under the same conditions in order to determine the variability from batch to batch. It can be seen in Table 3 that the second batch of Brass-filled PTFE performed the same as the first batch in a GOX environment and the reaction percentage decreased in a LOX environment from $5 \%$ in batch 1 to less than $2 \%$ in batch 2 . Two additional batches were tested at the same conditions and were shown to produce zero reactions out of the samples tested. A determination could be made through the batch mechanical impact screening that the compatibility of Brassfilled PTFE in high-pressure oxygen systems is not batch dependent.

In comparison to the Brass-filled PTFE, a similar metal filled PTFE compound named Salox-M ${ }^{\circledR}$ uses Bronze filler in PTFE instead of Brass. The composition of Salox-M ${ }^{\circledR}$ is $40 \%$ Bronze and $60 \%$ PTFE. The Bronze component of Salox-M ${ }^{\circledR}$ is made up of $90 \%$ Copper, $8 \%$ Tin, and $2 \%$ Zinc. Although the percentage of Brass in the Brass-filled PTFE is not known, it can be determined from figures 1 and 2 that it is far less than $40 \%$. Since the exact chemical make up of the Brass component or its relative percentage in Brass-filled PTFE is not known, it can only be speculated that the main component of the Brass is Zinc as opposed to the larger amount of Tin in the Bronze. The mechanical impact results for Salox-M® impacted with 98, 55, and 40 Joules at 10,000 psia in LOX are shown in Table 3. The results demonstrate that the relative percentage of Bronze to PTFE has a strong influence on the sensitivity of Salox-M® in an oxygen enriched environment.

The Salox-M® is much more reactive than the Brass-filled PTFE. In fact, reducing the pressure by $50 \%$ alone did not show the Salox-M® to be acceptable in an oxygen enriched environment. The impact energy was reduced by $50 \%$ in order to meet the pass/fail acceptance criteria. The sensitivity of Salox-M® in a high-pressure LOX environment has been shown to be far higher than that of the Brass-filled PTFE, which can be attributed to the high percentage of 
Bronze filler as well as the difference in the chemical composition of the Bronze as opposed to Brass.

Two types of Algoflon ${ }^{\circledR}$, another PTFE based material, were tested at the same conditions in order to compare them to the Brass-filled PTFE. Algoflon ${ }^{\circledR}$ E2 is a PTFE virgin granular resin which has been pre-sintered. This resin has been treated thermally at, or above, the melting point of the resin at atmospheric pressure. Algoflon ${ }^{\circledR}$ F7 is a PTFE virgin granular resin. It has been designed as a molding resin for use as thin skived tape with excellent skivability and good dielectric properties. As stated previously, two types of Algoflon ${ }^{\circledR}$ were tested, using both a LOX and GOX environment. It was shown that the pre-sintered E2 Algoflon ${ }^{\circledR}$ produced no reactions under the same conditions as the Brass-filled PTFE, whereas the F7 type did not perform well in a LOX environment. The F7 required the pressure to be dropped to 5,000 psia in order for the material to pass.

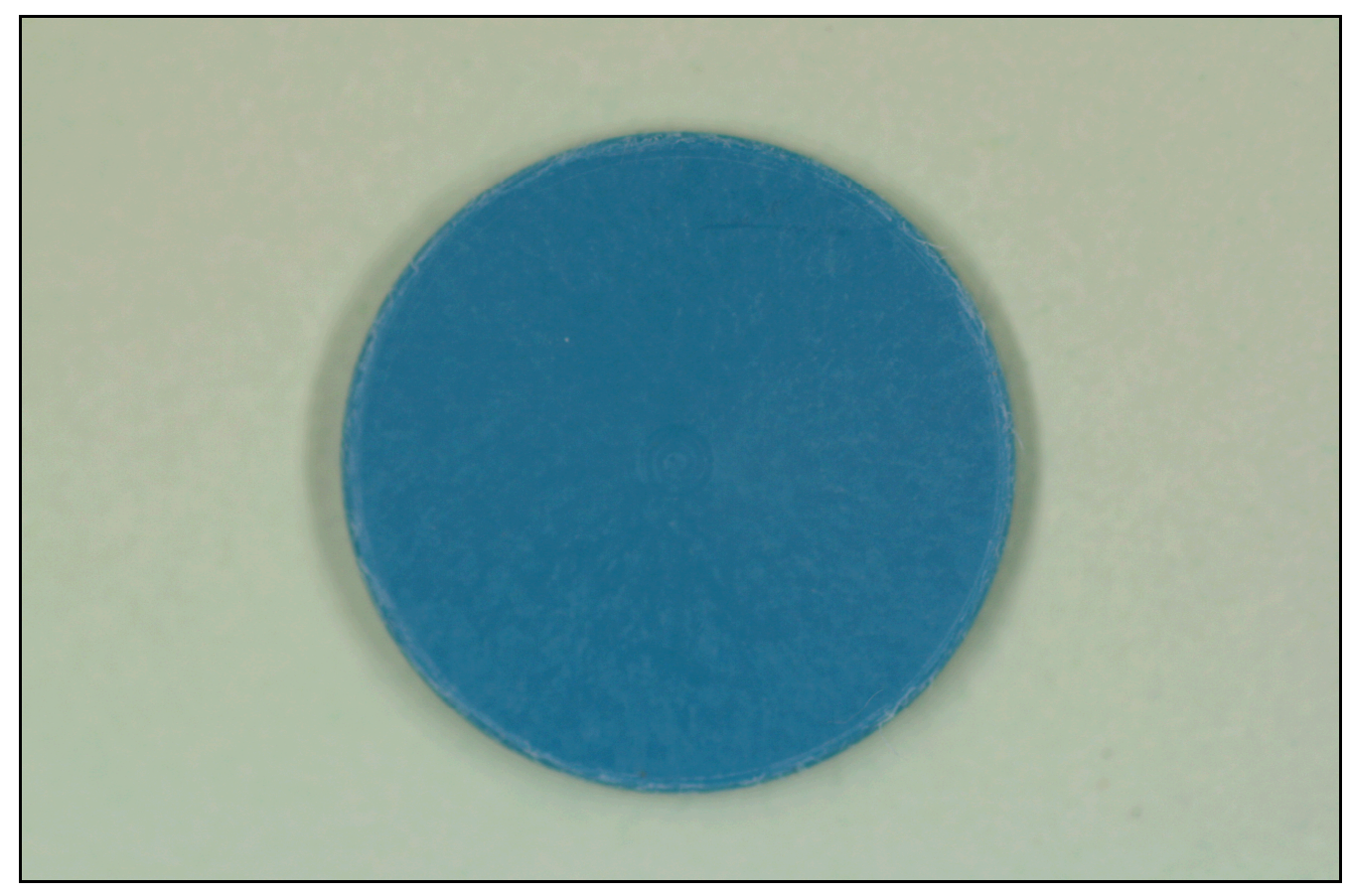

Figure - 1 Pretest photo of the Brass-filled PTFE 


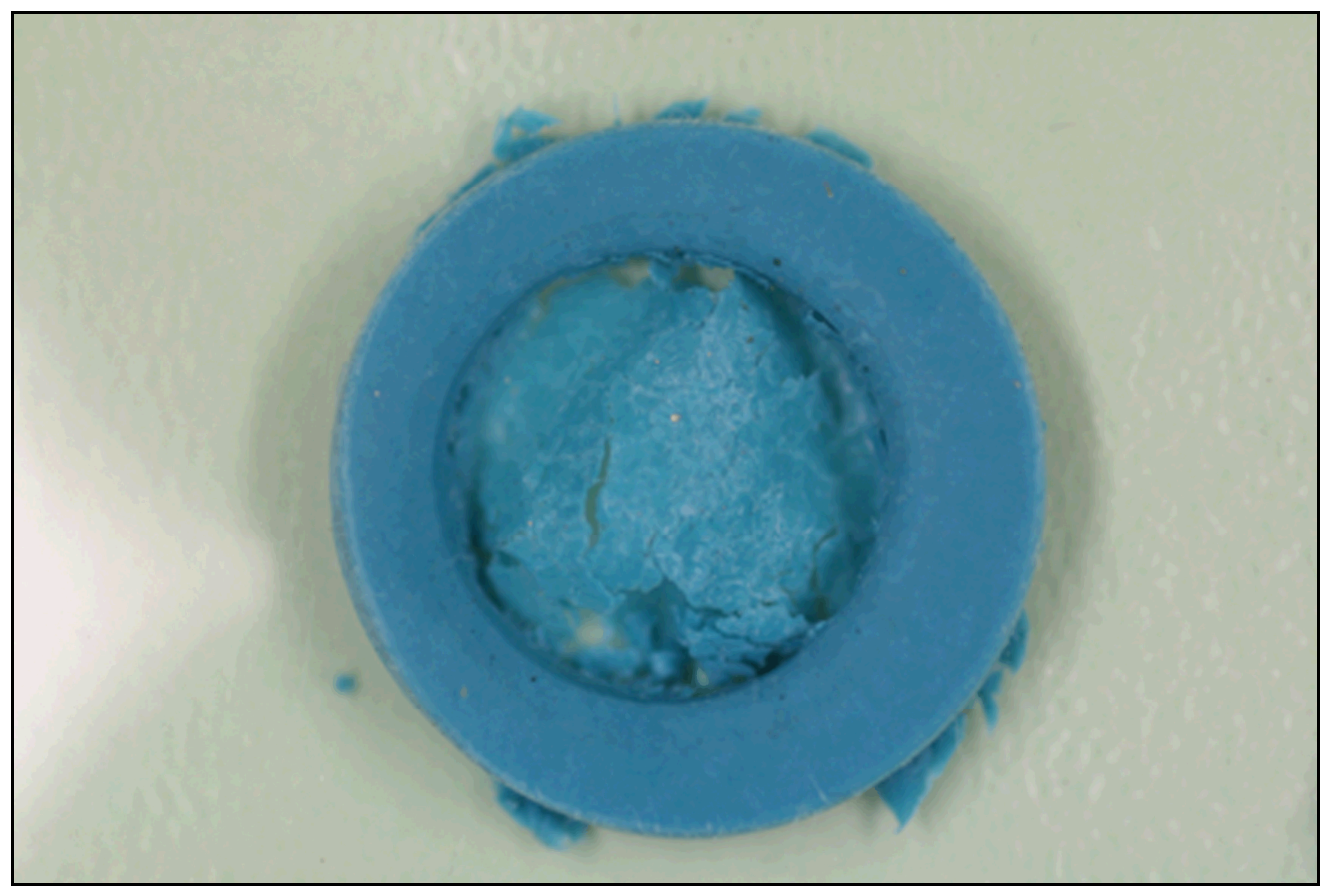

Figure - 2 Mechanical impact 10,000 psi GOX post test photo of the Brass-filled PTFE

TABLE 3-High Pressure Mechanical Impact Data of Fluorinated Compounds

\begin{tabular}{|c|c|c|c|c|c|}
\hline Material & $\begin{array}{c}\text { Impact Energy } \\
(\mathbf{f t}-\mathrm{lbs} / \mathbf{J})\end{array}$ & Test Conditions & $\begin{array}{c}\text { System } \\
\text { Pressure (psia) }\end{array}$ & $\begin{array}{l}\text { Average Sample } \\
\text { Thickness (inches) }\end{array}$ & $\begin{array}{l}\text { Reactions/ } \\
\text { Tests }\end{array}$ \\
\hline \multirow{4}{*}{$\begin{array}{l}{ }^{a} \text { Brass-filled PTFE } \\
(\text { Batch \#1) }\end{array}$} & $72 \mathrm{ft}-1 \mathrm{bs}(98 \mathrm{~J})$ & $\mathrm{LOX} /-297^{\circ} \mathrm{F}$ & 10,000 & 0.06802 & $0 / 20$ \\
\hline & 72 ft-lbs (98J) & $\mathrm{GOX} / 75^{\circ} \mathrm{F}$ & 10,000 & 0.06824 & $0 / 20$ \\
\hline & $72 \mathrm{ft}-\mathrm{lbs}(98 \mathrm{~J})$ & $\mathrm{LOX} /-297^{\circ} \mathrm{F}$ & 10,000 & 0.06823 & $4 / 80$ \\
\hline & $72 \mathrm{ft}-\mathrm{lbs}(98 \mathrm{~J})$ & $\mathrm{GOX} / 75^{\circ} \mathrm{F}$ & 10,000 & 0.06824 & $0 / 80$ \\
\hline \multirow{2}{*}{$\begin{array}{l}\text { aBrass-filled PTFE } \\
\text { (Batch \#2) }\end{array}$} & $72 \mathrm{ft}-\mathrm{lbs}(98 \mathrm{~J})$ & $\mathrm{GOX} / 75^{\circ} \mathrm{F}$ & 10,000 & 0.06206 & $0 / 20$ \\
\hline & $72 \mathrm{ft}-\mathrm{lbs}(98 \mathrm{~J})$ & $\mathrm{LOX} /-297^{\circ} \mathrm{F}$ & 10,000 & 0.06206 & $1 / 60$ \\
\hline \multirow{2}{*}{$\begin{array}{l}\text { aBass-filled PTFE } \\
\text { (Batch \#3) }\end{array}$} & $72 \mathrm{ft}-\mathrm{lbs}(98 \mathrm{~J})$ & $\mathrm{GOX} / 75^{\circ} \mathrm{F}$ & 10,000 & 0.06206 & $0 / 20$ \\
\hline & $72 \mathrm{ft}-\mathrm{lbs}(98 \mathrm{~J})$ & $\mathrm{LOX} /-297^{\circ} \mathrm{F}$ & 10,000 & 0.06206 & $0 / 20$ \\
\hline $\begin{array}{l}{ }^{\mathrm{a} B r a s s-f i l l e d ~ P T F E ~} \\
\text { (Batch \#4) }\end{array}$ & $72 \mathrm{ft}-\mathrm{lbs}(98 \mathrm{~J})$ & $\mathrm{GOX} / 75^{\circ} \mathrm{F}$ & 10,000 & 0.06206 & $0 / 20$ \\
\hline
\end{tabular}




\begin{tabular}{|c|c|c|c|c|c|}
\hline & $72 \mathrm{ft}-\mathrm{lbs}(98 \mathrm{~J})$ & $\mathrm{LOX} /-297^{\circ} \mathrm{F}$ & 10,000 & 0.06206 & $0 / 20$ \\
\hline \multirow[t]{5}{*}{${ }^{\mathrm{a}}$ Salox-M® } & $72 \mathrm{ft}-\mathrm{lbs}(98 \mathrm{~J})$ & $\mathrm{LOX} /-297^{\circ} \mathrm{F}$ & 10,000 & 0.06217 & $2 / 2$ \\
\hline & $55 \mathrm{ft}-\mathrm{lbs}(75 \mathrm{~J})$ & $\mathrm{LOX} /-297^{\circ} \mathrm{F}$ & 10,000 & 0.06256 & $2 / 4$ \\
\hline & $40 \mathrm{ft}-\mathrm{lbs}(54 \mathrm{~J})$ & $\mathrm{LOX} /-297^{\circ} \mathrm{F}$ & 10,000 & 0.06256 & $2 / 25$ \\
\hline & $50 \mathrm{ft}-\mathrm{lbs}(68 \mathrm{~J})$ & $\mathrm{LOX} /-297^{\circ} \mathrm{F}$ & 5,000 & 0.06256 & $2 / 18$ \\
\hline & $36 \mathrm{ft}-\mathrm{lbs}(39 \mathrm{~J})$ & $\mathrm{LOX} /-297^{\circ} \mathrm{F}$ & 5,000 & 0.06256 & $0 / 20$ \\
\hline \multirow[t]{7}{*}{${ }^{\mathrm{a}}$ Algoflon ${ }^{\circledR}$ F7 } & $72 \mathrm{ft}-\mathrm{lbs}(98 \mathrm{~J})$ & $\mathrm{GOX} / 75^{\circ} \mathrm{F}$ & 10,000 & 0.06217 & $0 / 20$ \\
\hline & $72 \mathrm{ft}-\mathrm{lbs}(98 \mathrm{~J})$ & $\mathrm{LOX} /-297^{\circ} \mathrm{F}$ & 10,000 & 0.06256 & $2 / 8$ \\
\hline & $72 \mathrm{ft}-\mathrm{lbs}(98 \mathrm{~J})$ & $\mathrm{LOX} /-297^{\circ} \mathrm{F}$ & 9,000 & 0.06256 & $2 / 3$ \\
\hline & $72 \mathrm{ft}-\mathrm{lbs}(98 \mathrm{~J})$ & $\mathrm{LOX} /-297^{\circ} \mathrm{F}$ & 8,000 & 0.06256 & $2 / 11$ \\
\hline & $72 \mathrm{ft}-\mathrm{lbs}(98 \mathrm{~J})$ & $\mathrm{LOX} /-297^{\circ} \mathrm{F}$ & 6,000 & 0.06256 & $2 / 4$ \\
\hline & $72 \mathrm{ft}-\mathrm{lbs}(98 \mathrm{~J})$ & $\mathrm{LOX} /-297^{\circ} \mathrm{F}$ & 5,000 & 0.06256 & $0 / 20$ \\
\hline & $72 \mathrm{ft}-\mathrm{lbs}(98 \mathrm{~J})$ & $\mathrm{LOX} /-297^{\circ} \mathrm{F}$ & 1,000 & 0.06256 & $0 / 20$ \\
\hline \multirow[t]{2}{*}{${ }^{\mathrm{a}}$ Algoflon ${ }^{\circledR}$ E2 } & $72 \mathrm{ft}-\mathrm{lbs}(98 \mathrm{~J})$ & $\mathrm{GOX} / 75^{\circ} \mathrm{F}$ & 10,000 & 0.0645 & $0 / 20$ \\
\hline & $72 \mathrm{ft}-\mathrm{lbs}(98 \mathrm{~J})$ & $\mathrm{LOX} /-297^{\circ} \mathrm{F}$ & 10,000 & 0.06202 & $0 / 20$ \\
\hline
\end{tabular}

$a-\quad$ NASA-STD $6001 \mathrm{MSFC}$

Previous research conducted in 1983 by C.J. Bryan at the John F. Kennedy Space Center, examined the oxygen compatibility of several different lubricants, polymers, and metals at varying energy levels of mechanical impact. The ambient-pressure mechanical impact data for some of their Fluorinated polymeric materials, in a LOX environment, was obtained from the research conducted by the Army Ballistic Missiles Agency (ABMA). The mechanical impact data is presented in Table 4 [3]. The results show that the compounds were not sensitive to mechanical shock at ambient pressure. The same Fluorinated compounds were then tested in a high-pressure LOX environment. The results of the mechanical impact tests under these conditions, as determined by data from the Kennedy Space Center, can be seen in Table 5. 
Teflon $®$ and Kel-F® 81 both passed the material acceptability test up to a pressure of 1,500 psia, whereas Fluorel $®$ began reacting at pressures above 500 psia; therefore, failing the test. These same materials were also tested in a GOX environment at ambient temperature and varying pressures. Previous work conducted at MSFC in 1972 determined that materials mechanically impacted were considerably more reactive in pressurized GOX than in a pressurized LOX environment [4]. By comparison of the Brass-filled PTFE in Table 3 to TFE-Teflon ${ }^{\circledR}$ (PTFE) in Table 5, it can be seen that their performance in high pressure LOX systems is very similar at 98 $\mathrm{J}$ and 0.062 inches in thickness. The results presented in Table 5 demonstrate the superior performance of the Brass-filled PTFE over Kel-F® 81 (PCTFE) and Fluorel ${ }^{\circledR}$.

The data presented in Table 6 are high-pressure GOX impact results determined by the testers at White Sands Test Facility (WSTF) and MSFC. In most cases, the reactivity of materials increases from either a decrease in thickness or an increase in pressure [2]. The data listed in Table 6 indicate that the reactivity of TFE-Teflon ${ }^{\circledR}$ (PTFE) tested at $72 \mathrm{ft}$-lbs with a sample thickness of 0.062 inches increases by $25 \%$ as the pressure is increased from 60 psia to 3,250 psia. The reactivity of the same material increases by $20 \%$ as the thickness of the material is decreased by half. Comparing TFE-Teflon ${ }^{\circledR}$ (PTFE) to Brass-filled PTFE, the data indicates that under the same conditions, i.e. thickness, impact energy and pressure, the Brass-filled PTFE outperforms the virgin PTFE. The data also shows that the Brass-filled PTFE significantly outperforms Kel-F® 81 (PCTFE) and Viton ${ }^{\circledR}$ A. The data presented in Table 6 depicts Fluorel ${ }^{\circledR}$ as having no reactions at varying pressures and sample thicknesses. However, it is not known how the material would behave at double the maximum pressure presented in the table. 
TABLE 4- Ambient Pressure Mechanical Impact Data of Fluorinated Compounds [4]

\begin{tabular}{|c|c|c|c|c|c|}
\hline Material & $\begin{array}{l}\text { Impact } \\
\text { Energy } \\
\text { lbs/J) }\end{array}$ & Test Conditions & $\begin{array}{l}\text { System } \\
\text { Pressure (psia) }\end{array}$ & $\begin{array}{l}\text { Average Sample } \\
\text { Thickness (inches) }\end{array}$ & $\begin{array}{l}\text { Reactions/ } \\
\text { Tests }\end{array}$ \\
\hline \multirow{3}{*}{$\begin{array}{l}{ }^{\mathrm{a}} \text { TFE-Teflon }{ }^{\circledR} \\
\text { (PTFE) }\end{array}$} & $72 \mathrm{ft}-\mathrm{lbs}(98 \mathrm{~J})$ & $\mathrm{LOX} /-297^{\circ} \mathrm{F}$ & Ambient & 0.00197 & $0 / 20$ \\
\hline & $72 \mathrm{ft}-\mathrm{lbs}(98 \mathrm{~J})$ & $\mathrm{LOX} /-297^{\circ} \mathrm{F}$ & Ambient & 0.062 & $0 / 100$ \\
\hline & $72 \mathrm{ft}-\mathrm{lbs}(98 \mathrm{~J})$ & $\mathrm{LOX} /-297^{\circ} \mathrm{F}$ & Ambient & 0.125 & $0 / 100$ \\
\hline \multirow{2}{*}{$\begin{array}{l}{ }^{\mathrm{a}} \mathrm{Kel-F} 81 \\
\text { (PCTFE) }\end{array}$} & $72 \mathrm{ft}-\mathrm{lbs}(98 \mathrm{~J})$ & $\mathrm{LOX} /-297^{\circ} \mathrm{F}$ & Ambient & 0.062 & $0 / 100$ \\
\hline & $72 \mathrm{ft}-\mathrm{lbs}(98 \mathrm{~J})$ & $\mathrm{LOX} /-297^{\circ} \mathrm{F}$ & Ambient & 0.125 & $0 / 100$ \\
\hline \multirow[t]{2}{*}{${ }^{\mathrm{a}}$ Viton ${ }^{\circledR} \mathrm{A}$} & $72 \mathrm{ft}-\mathrm{lbs}(98 \mathrm{~J})$ & $\mathrm{LOX} /-297^{\circ} \mathrm{F}$ & Ambient & 0.062 & $0 / 100$ \\
\hline & $72 \mathrm{ft}-\mathrm{lbs}(98 \mathrm{~J})$ & $\mathrm{LOX} /-297^{\circ} \mathrm{F}$ & Ambient & 0.125 & $0 / 200$ \\
\hline${ }^{\mathrm{a}}$ Fluorel ${ }^{\circledR}$ & $72 \mathrm{ft}-\mathrm{lbs}(98 \mathrm{~J})$ & $\mathrm{LOX} /-297^{\circ} \mathrm{F}$ & Ambient & 0.0645 & $0 / 100$ \\
\hline
\end{tabular}

a- Determined by ABMA

TABLE 5-High Pressure LOX Mechanical Impact Data of Fluorinated Compounds [4]

\begin{tabular}{|c|c|c|c|c|c|}
\hline Material & $\begin{array}{c}\text { Impact } \\
\text { Energy } \\
\text { (ft-lbs/J) }\end{array}$ & Test Conditions & $\begin{array}{c}\text { System } \\
\text { Pressure (psia) }\end{array}$ & $\begin{array}{l}\text { Average } \\
\text { Sample } \\
\text { Thickness } \\
\text { (inches) }\end{array}$ & $\begin{array}{c}\text { Reactions/ } \\
\text { Tests }\end{array}$ \\
\hline \multirow[t]{10}{*}{${ }^{\mathrm{a}}$ Fluorel ${ }^{\circledR}$} & $72 \mathrm{ft}-\mathrm{lbs}(98 \mathrm{~J})$ & $\mathrm{LOX} /-297^{\circ} \mathrm{F}$ & 14.5 & 0.06256 & $0 / 20$ \\
\hline & $72 \mathrm{ft}-1 \mathrm{bs}(98 \mathrm{~J})$ & $\mathrm{LOX} /-297^{\circ} \mathrm{F}$ & 100 & 0.06256 & $0 / 20$ \\
\hline & $72 \mathrm{ft}-\mathrm{lbs}(98 \mathrm{~J})$ & $\mathrm{LOX} /-297^{\circ} \mathrm{F}$ & 500 & 0.06256 & $0 / 20$ \\
\hline & $72 \mathrm{ft}-\mathrm{lbs}(98 \mathrm{~J})$ & $\mathrm{LOX} /-297^{\circ} \mathrm{F}$ & 1,000 & 0.06256 & $2 / 20$ \\
\hline & $72 \mathrm{ft}-\mathrm{lbs}(98 \mathrm{~J})$ & $\mathrm{LOX} /-297^{\circ} \mathrm{F}$ & 1,500 & 0.06256 & $2 / 20$ \\
\hline & $72 \mathrm{ft}-\mathrm{lbs}(98 \mathrm{~J})$ & $\mathrm{LOX} /-297^{\circ} \mathrm{F}$ & 14.5 & 0.125 & $0 / 20$ \\
\hline & $72 \mathrm{ft}-\mathrm{lbs}(98 \mathrm{~J})$ & $\mathrm{LOX} /-297^{\circ} \mathrm{F}$ & 100 & 0.125 & $0 / 20$ \\
\hline & $72 \mathrm{ft}-\mathrm{lbs}(98 \mathrm{~J})$ & $\mathrm{LOX} /-297^{\circ} \mathrm{F}$ & 500 & 0.125 & $3 / 20$ \\
\hline & $72 \mathrm{ft}-\mathrm{lbs}(98 \mathrm{~J})$ & $\mathrm{LOX} /-297^{\circ} \mathrm{F}$ & 1,000 & 0.125 & $4 / 20$ \\
\hline & $72 \mathrm{ft}-\mathrm{lbs}(98 \mathrm{~J})$ & $\mathrm{LOX} /-297^{\circ} \mathrm{F}$ & 1,500 & 0.125 & $6 / 20$ \\
\hline
\end{tabular}




\begin{tabular}{|c|c|c|c|c|c|}
\hline \multirow{2}{*}{$\begin{array}{c}{ }^{\mathrm{a}} \text { TFE-Teflon }{ }^{\circledR} \\
\text { (PTFE) }\end{array}$} & 72 ft-lbs (98J) & $\mathrm{LOX} /-297^{\circ} \mathrm{F}$ & 1,500 & 0.06256 & $0 / 20$ \\
\hline & $72 \mathrm{ft}-\mathrm{lbs}(98 \mathrm{~J})$ & $\mathrm{LOX} /-297^{\circ} \mathrm{F}$ & 1,500 & 0.125 & $0 / 20$ \\
\hline \multirow{2}{*}{$\begin{array}{c}{ }^{\mathrm{b}} \text { TFE-Teflon }{ }^{\circledR} \\
\text { (PTFE) }\end{array}$} & $72 \mathrm{ft}-\mathrm{lbs}(98 \mathrm{~J})$ & $\mathrm{LOX} /-297^{\circ} \mathrm{F}$ & 8,000 & 0.06256 & $2 / 3$ \\
\hline & $72 \mathrm{ft}-\mathrm{lbs}(98 \mathrm{~J})$ & $\mathrm{LOX} /-297^{\circ} \mathrm{F}$ & 10,000 & 0.06256 & $2 / 42$ \\
\hline \multirow{2}{*}{$\begin{array}{l}{ }^{\mathrm{a}} \mathrm{Kel-F} 81 \\
\text { (PCTFE) }\end{array}$} & $72 \mathrm{ft}-\mathrm{lbs}(98 \mathrm{~J})$ & $\mathrm{LOX} /-297^{\circ} \mathrm{F}$ & 1,500 & 0.06256 & $0 / 20$ \\
\hline & $72 \mathrm{ft}-\mathrm{lbs}(98 \mathrm{~J})$ & $\mathrm{LOX} /-297^{\circ} \mathrm{F}$ & 1,500 & 0.125 & $0 / 20$ \\
\hline b & $72 \mathrm{ft}-\mathrm{lbs}(98 \mathrm{~J})$ & $\mathrm{LOX} /-297^{\circ} \mathrm{F}$ & 2,000 & 0.06256 & $8 / 20$ \\
\hline
\end{tabular}

a- MSFC and WSTF mechanical impact test results

$\boldsymbol{b}$ - Obtained from MAPTIS

TABLE 6-High Pressure GOX Mechanical Impact Data of Fluorinated Compounds [4]

\begin{tabular}{|c|c|c|c|c|c|}
\hline Material & $\begin{array}{c}\text { Impact Energy } \\
\text { (ft-lbs/J) }\end{array}$ & Test Conditions & $\begin{array}{c}\text { System } \\
\text { Pressure (psia) }\end{array}$ & $\begin{array}{c}\text { Average } \\
\text { Sample } \\
\text { Thickness } \\
\text { (inches) }\end{array}$ & $\begin{array}{c}\text { Reactions / } \\
\text { Tests }\end{array}$ \\
\hline \multirow{5}{*}{$\begin{array}{l}{ }^{\mathrm{a}} \text { TFE-Teflon }{ }^{\circledR} \\
\text { (PTFE) }\end{array}$} & $72 \mathrm{ft}-\mathrm{lbs}(98 \mathrm{~J})$ & $\mathrm{GOX} / 260^{\circ} \mathrm{F}$ & 60 & 0.06256 & $0 / 20$ \\
\hline & 72 ft-lbs (98J) & $\mathrm{GOX} / 177^{\circ} \mathrm{F}$ & 3,250 & 0.06256 & $5 / 20$ \\
\hline & $20.3 \mathrm{ft}-\mathrm{lbs}(27.5 \mathrm{~J})$ & $\mathrm{GOX} / 177^{\circ} \mathrm{F}$ & 3,250 & 0.06256 & $0 / 20$ \\
\hline & $72 \mathrm{ft}-\mathrm{lbs}(98 \mathrm{~J})$ & GOX/Ambient & 5,000 & 0.125 & $0 / 20$ \\
\hline & $72 \mathrm{ft}-\mathrm{lbs}(98 \mathrm{~J})$ & GOX/Ambient & 5,000 & 0.06256 & $4 / 20$ \\
\hline \multirow{2}{*}{$\begin{array}{l}{ }^{\mathrm{b}} \text { TFE-Teflon }{ }^{\circledR} \\
\text { (PTFE) }\end{array}$} & $72 \mathrm{ft}-\mathrm{lbs}(98 \mathrm{~J})$ & GOX/Ambient & 7,000 & 0.06256 & $2 / 5$ \\
\hline & $72 \mathrm{ft}-\mathrm{lbs}(98 \mathrm{~J})$ & GOX/Ambient & 8,000 & 0.06256 & $1 / 1$ \\
\hline \multirow{7}{*}{$\begin{array}{lll}{ }^{\mathrm{a}} \text { Kel-F }{ }^{\circledR} & 8 & 1 \\
\text { (PCTFE) } & & \end{array}$} & 72 ft-lbs (98J) & GOX/Ambient & 1,000 & 0.06256 & $0 / 20$ \\
\hline & $50 \mathrm{ft}-\mathrm{lbs}(68 \mathrm{~J})$ & GOX/Ambient & 1,500 & 0.06256 & $2 / 20$ \\
\hline & $43 \mathrm{ft}-\mathrm{lbs}(59 \mathrm{~J})$ & GOX/Ambient & 1,500 & 0.06256 & $0 / 20$ \\
\hline & $40 \mathrm{ft}-\mathrm{lbs}(54 \mathrm{~J})$ & GOX/Ambient & 2,000 & 0.06256 & $0 / 20$ \\
\hline & $45 \mathrm{ft}-\mathrm{lbs}(61 \mathrm{~J})$ & GOX/Ambient & 3,000 & 0.06256 & $0 / 20$ \\
\hline & $55 \mathrm{ft}-\mathrm{lbs}(75 \mathrm{~J})$ & GOX/Ambient & 5,000 & 0.06256 & $1 / 6$ \\
\hline & $40 \mathrm{ft}-\mathrm{lbs}(54 \mathrm{~J})$ & GOX/Ambient & 5,000 & 0.06256 & $0 / 20$ \\
\hline
\end{tabular}




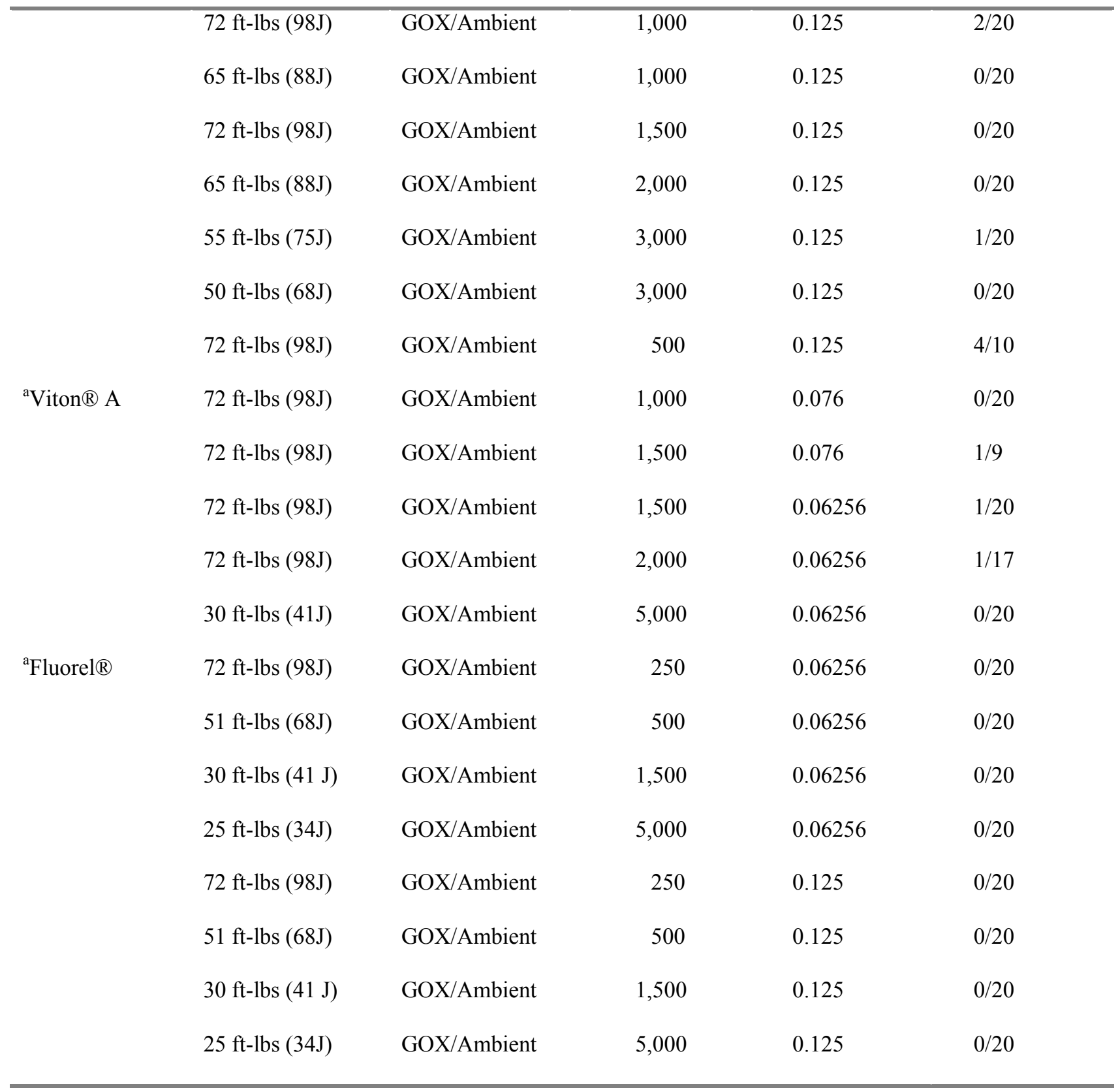

a- MSFC and WSTF mechanical impact test results

$\boldsymbol{b}$ - Obtained from MAPTIS 


\section{Conclusions}

Polymeric materials, such as TFE-Teflon ${ }^{\circledR}$ (PTFE), have proven to be reliable and safe materials for use as seats and seals in oxygen systems. The search for a polymer that performs as well as TFE-Teflon ${ }^{\circledR}$ (PTFE), in terms of oxygen compatibility, and also maintains its physical integrity at high pressures and cryogenic temperatures has become an ongoing expedition. Through research at the Materials Combustion Research Facility at Marshall Space Flight Center a Brass-filled polytetrafluoroethylene has been uncovered that exemplifies all of the positive characteristics that are valued in an oxygen compatible material. The low heat of combustion, elevated AIT, and very high resistance to mechanical shock in pressurized LOX and GOX environments further exemplify the suitability of the Brass-filled PTFE for oxygen systems. The data presented clearly show that the choice of the filler material and the percentage of filler relative to PTFE can make all the difference in a high-performing oxygen compatible material. Even though the Brass-filled PTFE performs similarly to TFE-Teflon ${ }^{\circledR}$ in a high-pressure LOX environment, its performance far exceeds that of TFE-Teflon ${ }^{\circledR}$ in a high-pressure GOX environment, which makes Brass-filled PTFE the best choice for oxygen systems. 


\section{References}

[1] Chou, T. C. and Fiedorowicz, A., "Oxygen Compatibility of Polymers Including TFETeflon ${ }^{\circledR}$, Kel-F® 81, Vespel ${ }^{\circledR}$ SP-21, Viton ${ }^{\circledR}$ A, Viton ${ }^{\circledR}$ A-500, Fluorel $₫$, Neopreneg, EPDM, Buna-N, and Nylon 6,6," Flammability and Sensitivity of Materials in OxygenEnriched Atmospheres: Eighth Volume, ASTM STP 1319, W. T. Royals, T. C. Chou, and T. A. Steinberg, Eds., American Society for Testing and Materials, 1997.

[2] Beeson, H.D., Smith, S.R., Stewart, W.F., "Safe Use of Oxygen and Oxygen Systems: Handbook for Design, Operation, and Maintenance $2^{\text {nd }}$ Edition" American Society for Testing and Materials, 2007.

[3] Bryan, C. J., "NASA Mechanical Impact Testing in High-Pressure oxygen," Flammability and Sensitivity of Materials in Oxygen-Enriched Atmospheres, ASTM STP 812, B. L. Werley, Ed., American Society for Testing and Materials, 1983, pp. 9-42.

[4] Schwinghamer, R. J., "Impact Sensitivity of Materials in Contact with Liquid and Gaseous Oxygen at High Pressure," NASA Technical Memorandum TMX-64634, National Aeronautics and Space Administration, Washington, D. C., Jan. 1972. 